\title{
Usefulness of Mobile Information Provision Systems Using Graphic Text - Visibility of Graphic Text on Mobile Phones
}

\author{
Tomoyuki Watanabe ${ }^{1}$, Masako Omori ${ }^{2}$, Satoshi Hasegawa ${ }^{3}$, Shohei Matsunuma ${ }^{4}$, \\ and Masaru Miyao ${ }^{5}$ \\ ${ }^{1}$ Faculty of Psychological and Physical Science, Aich-Gakuin University, 12 Araike, \\ Iwasaki-cho, Nisshin 470-0195, Japan \\ wtomo709@dpc.aichi-gakuin.ac.jp \\ ${ }^{2}$ Faculty of Home Economics, Kobe University, 2-1 Aoyama Higashisuma, Suma-ku, \\ Kobe 654-8585, Japan \\ masako@suma.kobe-wu.ac.jp \\ ${ }^{3}$ Dept. of Information Culture, Nagoya Bunri University, 365 Maeda Inazawa-cho, \\ Inazawa, Aichi 492-8520, Japan \\ hsgwsts@gmail.com \\ ${ }^{4}$ Nagoya Institute of Technology, Gokiso-cho, Showa-ku, Nagoya, Aichi, 466-8555, Japan \\ stmat6866@nexyzbb.ne.jp \\ ${ }^{5}$ Information Technology Center, Nagoya University, Furo-cho, Chikusa-Ku, \\ Nagoya 464-8601, Japan \\ miyao@med.nagoya-u.ac.jp
}

\begin{abstract}
Textual information can be sent as graphic images without being coded in the broadband digital network. By using graphic text, characters or symbols with unsupported fonts can be displayed. Graphical e-mail systems in mobile phones for sending digital photographs are useful in sending graphic text. We researched the visibility of graphic text on the liquid crystal displays in mobile phones comparing with that of font in the mobile phones, by measuring the variables of reading time and visual distance. We also recorded the number of errors, and subjects evaluated the visibility. Graphic text prepared in the JPEG format had nearly the same visibility of the original font. However, it must be noted that visibility deteriorates as the character size become smaller, and as the user become older. We also mention about the possibility of multilingual disaster information system with mobile phones as an application of the graphic text. Graphic text enables easy display of multilingual information by ordinary types of mobile phones which does not support multilingual characters.
\end{abstract}

Keywords: graphical character, digital photo e-mail, size of character, disaster information, multilingual text.

\section{Introduction}

The increasing use of broadband in the information network is making it possible to send and receive large amounts of data, and the exchange of graphic data on mobile phones and other mobile information devices is becoming common. With this 
technology textual information can be sent and received as graphic images, without being coded for communication. The usefulness of optical character recognition systems that convert graphic textual information into coded text is clear, but there are also various possible applications for "graphic text" in which textual information is converted to graphic image data.

The advantage of graphic text is that it is not limited by the display functions of the terminal. Thus, text can be displayed freely in terms of language, letter or character shape, and arrangement, controlled by the display layout at the information source. In addition, symbols and pictograms other than letters can be used, and combinations of pictures and letters such as in maps or comics can be easily realized.

We report here the results of an assessment of the visibility [1-3] of graphic text on liquid crystal displays, with the aim of realizing a multilingual information provision system using graphic text for mobile phones [4]. We also discuss possible applications of graphic text.

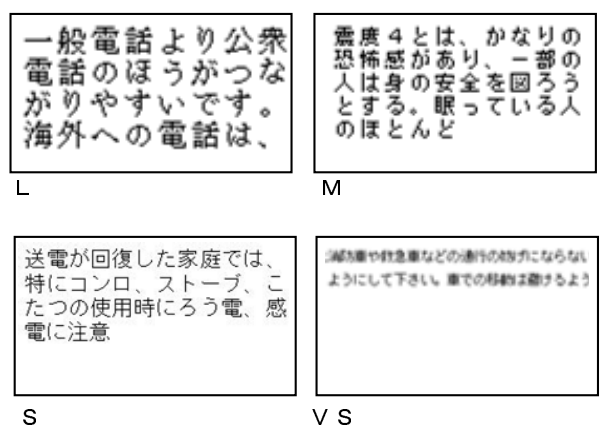

Fig. 1. Examples of graphic text used in visibility assessment experiment. Short Japanese sentences are presented in the JPEG format. Width of these images are the same as the resolutions of the mobile phones used in the experiments. Large (L): 8 characters/line. Medium (M): 10 characters/line. Small (S): 12 characters/line. Very Small (VS): 20 characters/line.

\section{Visibility Experiment}

\subsection{Aim}

The aim of this experiment was to investigate the visibility of graphic text (Fig. 1) on mobile phone liquid crystal displays (LCDs), in order to clarify the possibilities and problems for mobile phones as information supply systems using graphic text. We performed the following 3 experiments.

Experiment 1: Comparison of fonts and graphic text. Experiment 2: Influence of text size on visibility. Experiment 3: Differences in visibility depending on subject age.

\subsection{Methods}

Experiment 1: The subjects were 28 Japanese males and females aged 20-41 years $(24.8 \pm 6.9$ years). The mobile phone used was a Sharp SH53 (240 x 320 dot, 2.4 inch 
CG Silicon LCD). Four samples were used: (1) font (character size: small), (2) graphic text (small), (3) font (very small), and (4) graphic text (very small). Examples of character size are shown in Fig. 1.

Experiment 2: The subjects were 24 Japanese males and females aged 21-28 years (23.2 \pm 1.8 years). The mobile phone used was a Sanyo SA51 (2.1 inch, 132 dot width, TFT color LCD). Three graphic text samples were used: (1) large, (2) medium, and (3) small (Fig. 1).

Experiment 3: The subjects were 88 Japanese males and females aged 20-79 years $(46.3 \pm 17.9$ years). There were 41 people in the young age group of 20-39 years $(29.3$ \pm 6.2 years), 14 in the middle-aged group of $40-59$ years ( $47.6 \pm 6.8$ years), and 33 in the elderly group of 60-79 years $(66.4 \pm 4.7$ years). The mobile phone used was a Sanyo SA51 (same as Experiment 2). The three types of graphic text used were (1) large, (2) medium, and (3) small (Fig. 1).

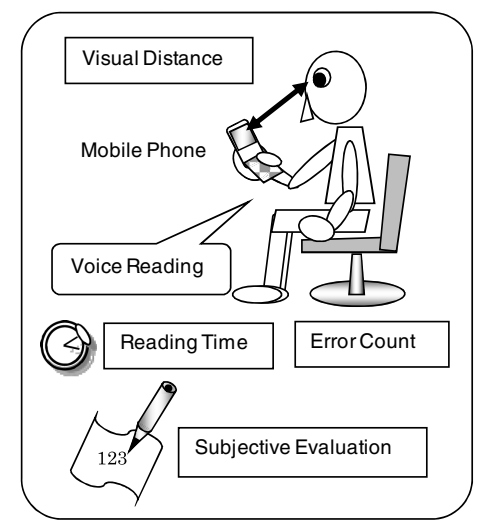

Fig. 2. Items measured in evaluating visibility. Subjects sit on the chair and read aloud the sentences displayed on the LCD in the mobile phone. Visual distance, reading time and number of error were measured. Subjective evaluation was recorded every after reading.

The graphic text used in the experiments was prepared in the MS-Mincho typeface in Joint Photographic coding Expert Group (JPEG) format. The character sizes were large (8 characters/line), medium (10 characters/line), small (12 characters/line), and very small (20 characters/line) (Fig. 1). The graphic text was prepared to match the resolution of the liquid crystal in the mobile phone used in each experiment, so that it filled a single screen without scrolling. The text samples were prepared in sufficient variation so that no subject read the same text more than once, and the samples were displayed in rotation so as to avoid influence from the order and content of the text. Subjects used eyeglasses as needed according to their normal habits, and read aloud the text shown on the liquid crystal display of the mobile phone.

An examiner recorded the time to read the text, number of errors, and visual distance (Fig. 2). After reading the text, the subjects graded (subjective evaluation) the ease of reading on a 5-point scale (5: very easy to read -1: very difficult to read). 


\subsection{Results}

Measured parameters shown in Fig. 2, reading speed (character/sec.) (= number of characters / reading time $)$ and error rate $(\%)(=100 \times$ error count / character $)$ were statistically analyzed. Results of the experiment 1, 2 and 3 were shown in Fig. 3, 4 and 5 , respectively.

Experiment 1 (see Fig. 3): The results of a two-way ANOVA with character size (small or very small) and type of text data (font or graphic text) as factors showed that only character size was significant as a main effect in subjective evaluation $(\mathrm{p}<0.0001)$ and visual distance $(\mathrm{p}=0.0121)$. Neither the type of data nor the interaction had a significant effect. The p-values shown in the Fig. 3 are the results of t-test conducted with mean values, with consideration of application to each subject. In this test, subjective evaluation, reading speed and visual distance were uniformly lower significantly in very small size than in small size, although the type of text data had no significant effect. Almost no error was detected in this experiment.

Experiment 2 (see Fig. 4): The effect of character size (large, medium, small) was examined, and with smaller character size the subjective evaluation of reading ease decreased, reading speed decreased, and visual distance became shorter. Significant differences by one-way ANOVA were seen in the subjective evaluation as shown in Fig. 4. Most subjects could read perfectly so that error rate was $<0.005 \%$ in average (few subject took at most 2 mistakes while reading 45 characters), and that rare had no significant difference between the size of characters.

Experiment 3 (see Fig. 5): The results of a two-way ANOVA with character size (large, medium, small) and age groups of subjects (young, middle-aged, elderly) as factors showed that both of them were significant as main effects in reading speed (both $\mathrm{p}<0.0001$ ). The interaction had no significant effect. The reading speed and error rate increased as subjects became older. 5 person in elderly group of 33 person $(15.2 \%)$ could not complete reading graphic characters of small size because of bad view. These 5 were excepted from the data of elderly (60-79) and size $S$ in reading speed and error rate. No difference was seen between the different age groups in the subjective evaluation. Although visual distance became shorter as character size become smaller in young and middle-aged group, visual distance increased with subject age, and among the elderly subjects no significant difference was seen with character size. The p-values shown in Fig. 5 are the significant differences among character size in the results of the two-way ANOVA and the differences among the age groups by a one-way ANOVA in individual character size.

\subsection{Discussion}

The decrease in the parameters of subjective evaluation, reading speed and visual distance in young people with normal uncorrected or corrected vision was thought to be a result of decreased visibility. Bad visibility should also cause an increase of the error count.

It was seen from the results of Experiment 1 comparing visibility of font and graphic text that graphic text prepared in the JPEG format had nearly the same visibility as the font included in the mobile phone. Moreover, it was seen from 


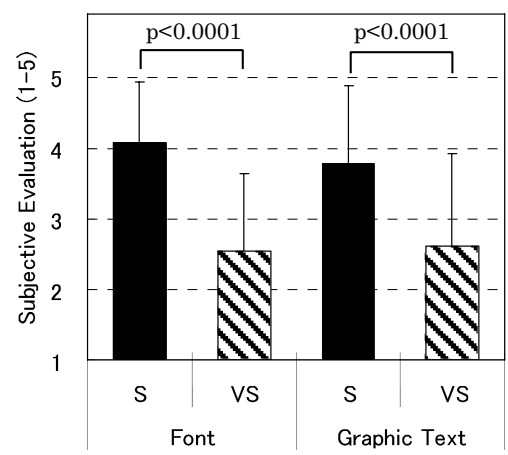

(a) Subjective Evaluation

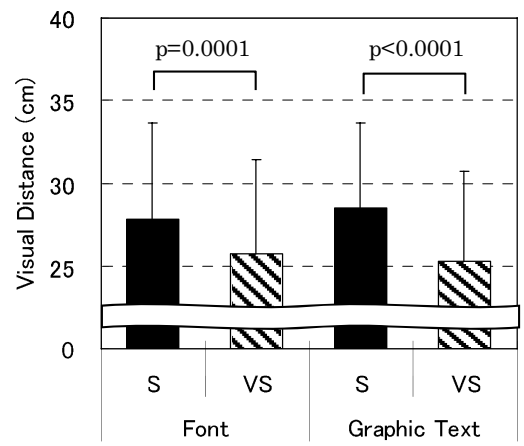

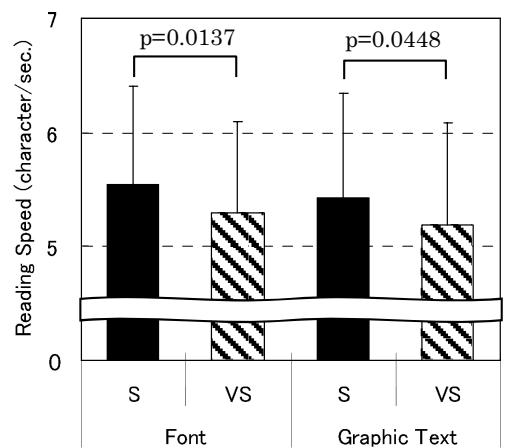

(b) Reading Speed

(c) Visual Distance

Fig. 3. Experiment 1, comparison of visibility of font and graphic text

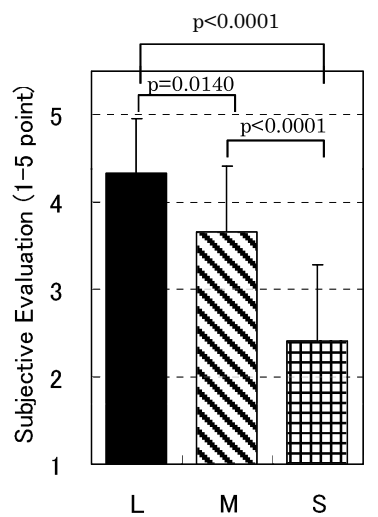

(a) Subjective Evaluation

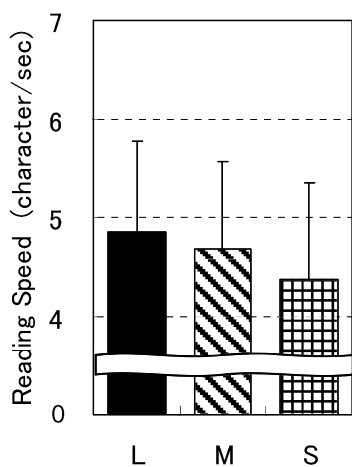

(b) Reading Speed

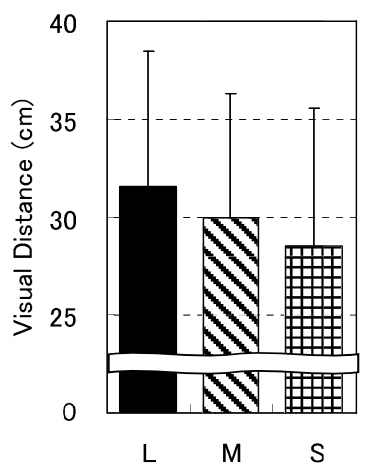

(c) Visual Distance

Fig. 4. Experiment 2, visibility and font size 


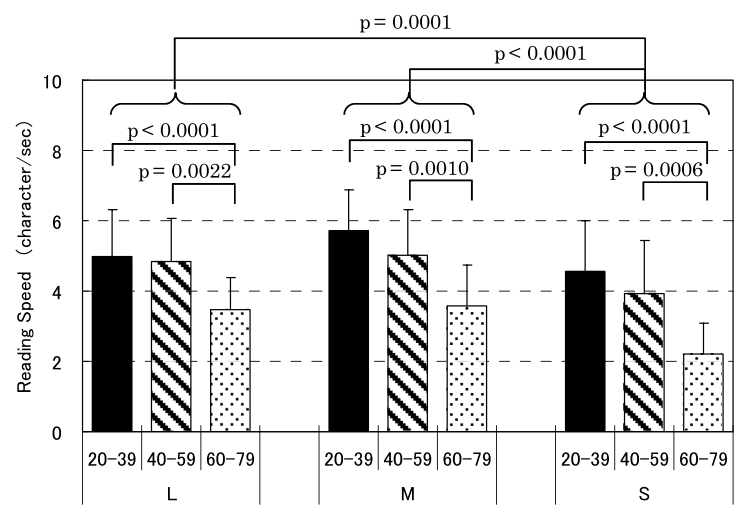

(a) Reading Speed

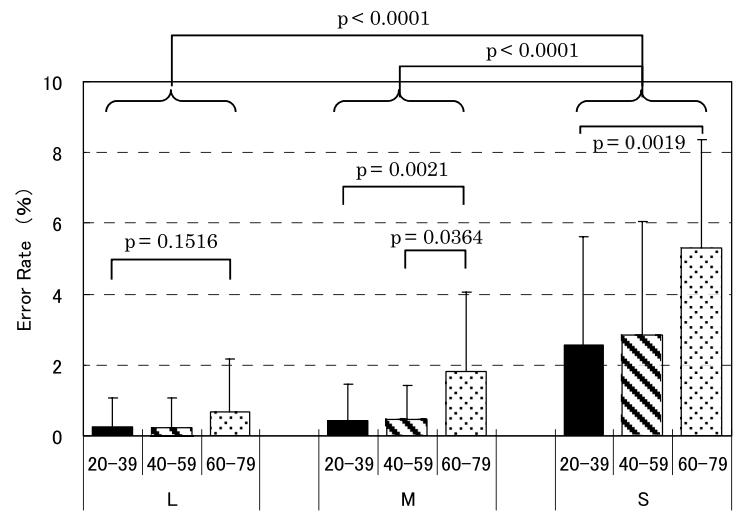

(b) Error Rate

Fig. 5. Experiment 3, visibility of graphic text by age. Young: 20-39, Middle-aged: 40-59, Elderly: 60-79 years old.

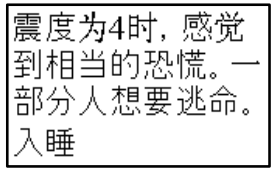

\begin{tabular}{|l|}
\hline 실외로 대피할 \\
때는 신을 신고 \\
머리를 보호할 수 \\
있는 모자 또는 \\
쿠션을 사용하시기 \\
바랍니
\end{tabular}

We provide
information in
English to
people who are
suffering from
the earthquake.

Fig. 6. Multilingual graphic text (Chinese, Korean, English)

Experiment 2 that visibility decreases with smaller character size, and from Experiment 3 that visibility was lower for the elderly, especially when character size was small. 


\section{Possibility of Information Provision System Using Graphic Text}

The results for subjective evaluation of visibility in the previous section indicate that, in phone models with comparatively high resolution and brightness, the visibility of graphic text on mobile phone LCDs is nearly equivalent to that of fonts.

Even with lossy compression of the JPEG format, it was found that graphic text compressed to the size that can be transmitted on today's mobile phones has sufficient picture quality in terms of visibility for reception on a mobile terminal. However, caution is needed since visibility decreases with smaller character sizes, especially for older people.

Providing information as graphic text allows the text to be displayed in fonts or display formats not handled by the mobile terminal. For example, mobile phones in most countries display text in the letters or characters of the language of that country plus alphanumeric characters. With graphic text, however, these phones can display multiple languages. Nearly all mobile phones in Japan are equipped to handle only alphanumeric characters and the Japanese language, but Chinese, Korean, or other languages sent as graphic text (Fig. 6) can be received by anyone in Japan regardless of the model of phone they are using.

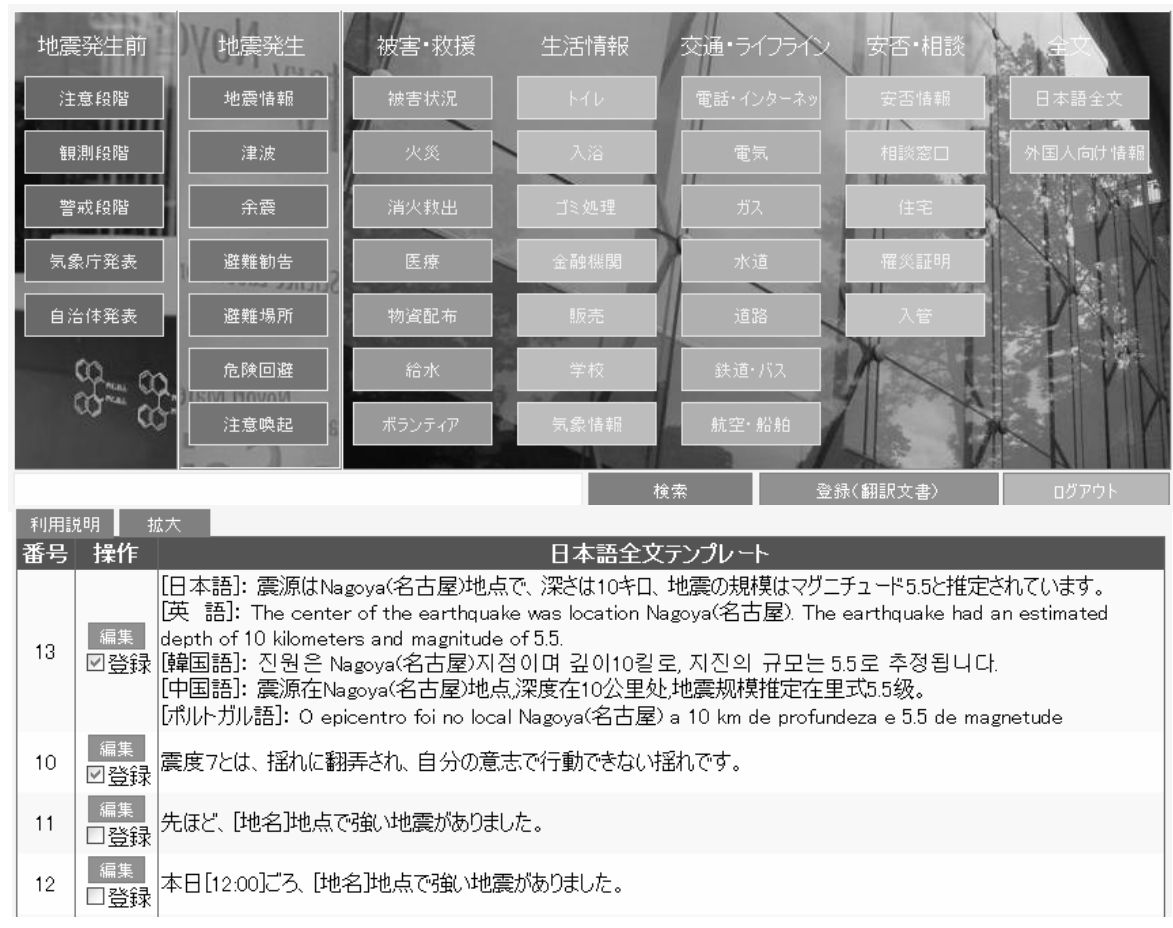

Fig. 7. Template system for translating disaster information into multiple languages. This system is a Web application. Buttons of 38 categories concern with disaster information and 2 listing function are shown in the upper area of this page. Template sentences in the selected category are shown in the lower area. 


\begin{tabular}{|c|c|c|c|c|c|c|}
\hline & \multirow{2}{*}{ No. } & テキスト(UTF-8) Mウンロート & $2>0-k$ & & & \multirow[t]{2}{*}{ ロ只ウト } \\
\hline & & 日本語 & 英語 & 韓国俉 & 中国語 & \\
\hline 選抎 & 22 & 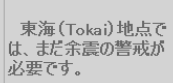 & $\begin{array}{l}\text { Precautions are necessary } \\
\text { for further aftershocks at } \\
\text { location 東海 (Tokai). }\end{array}$ & $\begin{array}{l}\text { 東海 (Tokai) 지점은 } \\
\text { 여진의 경계가 필 } \\
\text { 요합니다. }\end{array}$ & $\begin{array}{l}\text { 在東海 (Tokai) 地 } \\
\text { 点有必要注意余 } \\
\text { 震。 }\end{array}$ & $\begin{array}{l}\text { É necessário precaucão } \\
\text { contra pequenos abalos } \\
\text { nos seguintes locais 東海 } \\
\text { (Tokai). }\end{array}$ \\
\hline 退択 & 23 & $\begin{array}{l}\text { 亀裂が入っていたり傾 } \\
\text { いてりする住宅はは余 } \\
\text { 震によって倒壊する恐れ } \\
\text { がありますので絶対に } \\
\text { 立ち入らないて下さい。 }\end{array}$ & $\begin{array}{l}\text { Houses that have cracks or } \\
\text { are leaning should NOT be } \\
\text { entered, because of the } \\
\text { danger that they will collapse } \\
\text { in an aftershock }\end{array}$ & $\begin{array}{l}\text { 균열이 생기거나 기 } \\
\text { 훟어진 주택응 여진 } \\
\text { 으ㄹㅗㅗ무너질 우려가 } \\
\text { 있으므ㄹㅗㅗ절대 들어 } \\
\text { 가지 마십시오. }\end{array}$ & $\begin{array}{l}\text { 有裂缝和倾斜的房 } \\
\text { 屋由于杀震影响有 } \\
\text { 可能发生倒埸, 请 } \\
\text { 绝对不要靠近和进 } \\
\text { 入。 }\end{array}$ & $\begin{array}{l}\text { Não entrar e nem se } \\
\text { aproximar de prédios com } \\
\text { rachaduras, pois há perigo de } \\
\text { desabamento, mesmo com } \\
\text { pequenos abalos. }\end{array}$ \\
\hline 選根 & 11 & $\begin{array}{l}\text { 先ほど、名古屋 } \\
\text { (Nagoya)地点で強い地 } \\
\text { 震力゙ありました。 }\end{array}$ & $\begin{array}{l}\text { A short time ago there was a } \\
\text { strong earthquake at location } \\
\text { 名古屋(Nagoya). }\end{array}$ & $\begin{array}{l}\text { 조금 전 염古屋 } \\
\text { (Nagoya)지점에서 강 } \\
\text { 한 지진이 있었습니 } \\
\text { 다. }\end{array}$ & $\begin{array}{l}\text { 刚才,在名古屋 } \\
\text { (Nagoya)地点发生 } \\
\text { 强烈地震。 }\end{array}$ & $\begin{array}{l}\text { Ocorreu forte abalo há } \\
\text { poucos minutos em local 名 } \\
\text { 古屋(Nagoya). }\end{array}$ \\
\hline 邆択 & 315 & $\begin{array}{l}\text { 気象庁では、この変化 } \\
\text { と東海地震との関連性 } \\
\text { につき調査中です。 }\end{array}$ & $\begin{array}{l}\text { The Meteorological Agency is } \\
\text { investigating whether these } \\
\text { changes are associated with } \\
\text { the Tokai Earthquake. }\end{array}$ & $\begin{array}{l}\text { 기상청에서는 이 변 } \\
\text { 화와 도오카이지진 } \\
\text { 과의 관련성에 대해 } \\
\text { 조사중입니다. }\end{array}$ & $\begin{array}{l}\text { 气象厅正在调查本 } \\
\text { 变化与东海地震的 } \\
\text { 关联性。 }\end{array}$ & $\begin{array}{l}\text { A Agência de Meteorologia } \\
\text { está analisando a relacão } \\
\text { destes dados com o } \\
\text { Terremoto de Tokai. }\end{array}$ \\
\hline
\end{tabular}

Fig. 8. Examples of multilingual sentences translated by the template disaster information system (shown in Fig. 7). By filling blanks in Japanese template, English, Korean, Chinese and Portuguese text are available.

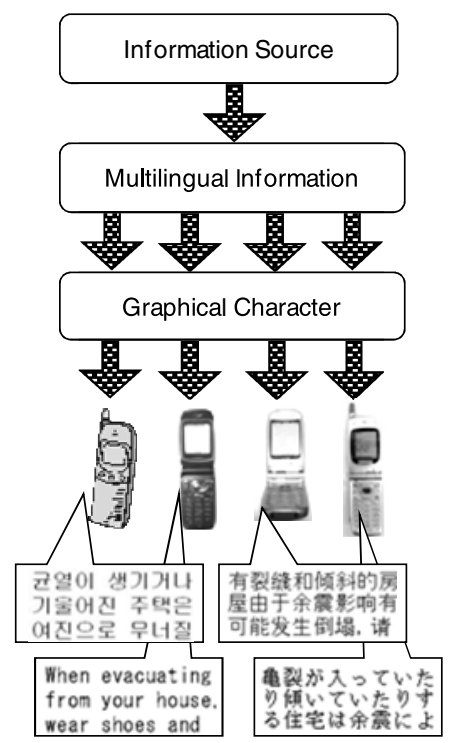

Fig. 9. Provision of multilingual information through graphic e-mail

The authors' group has already developed a multilingual template translation system [5] to provide information in time of disasters (Fig. 7). This system is a Web application. More than 500 sentences and their translated templates are recorded in this system of the current version. These templates has categorized in 6 main categories and 38 detailed categories concerning with disaster information, especially with earthquake information as shown in Fig. 7. Buttons of these 38 categories and buttons to list up all Japanese templates and to select information for foreigners are 
shown in the upper part of the page (Fig. 7). With Japanese as the template, information such as places or times can be input as necessary and instantly output as sentences translated into English, Korean, Chinese, Portuguese, and other languages. Each template sentence is related to disaster and disaster prevention, and is short enough to be sent to mobile phones as graphic text (Fig. 8). A possible flow of a mobile information provision system using graphic text is shown in Fig. 9.

Moreover, in languages such as English and Korean in which there is a space between words, appropriate line breaks have a great effect on readability. Such languages become more difficult to read if line breaks occur in the middle of words. With graphic text, however, appropriate line breaks can be placed in advance by the sender in the graphic text layout, so that the displayed text is easy to read even if the receiver's phone does not have such a line break function like ordinary models of mobile phones used in Japan now (Fig. 10). This is another example of the application of graphic text.

Another advantage of graphic text is that pictograms and special symbols other than letters can be used, making it easy to combine maps and words, for example. Handwritten text can also be sent as is.

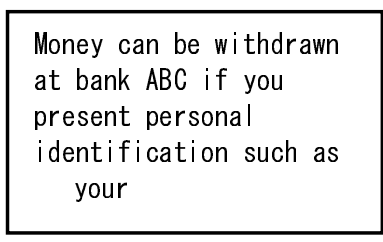

(a) Graphic text

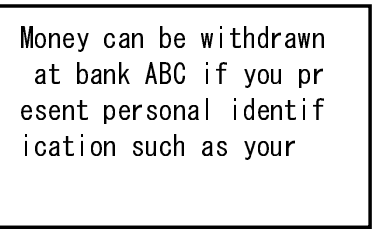

(b) Font

Fig. 10. Appropriate line breaks with graphic text

\section{Conclusion and Future Issues}

With the aim of developing a mobile information provision system using graphic text, we experimentally assessed the visibility of graphic text on mobile phone displays, and found that graphic text is useful in displaying written information. Graphic text enables easy display of information in multiple languages, and has the advantage that text size and layout can be controlled by the sender.

It should be useful in providing disaster prevention and emergency information to foreign residents of Japan, the aged, or persons with certain disabilities who may be at a disadvantage in terms of obtaining information. A multilingual information provision system using template translation will make it possible to provide information to people from other countries.

However, caution is needed in displays intended for the elderly $[1,3]$, as many have difficulty reading small characters $[2,6]$. To realize universal design [6-8], it may be necessary to have a text scaling function on the user's side. Future issues will be compatibility of the display when providing information using combinations of graphic text and fonts, and realization and validation of bidirectional conversion between graphic text and fonts using character recognition systems that convert between graphic and font-based text. 


\section{References}

1. Omori, M., Watanabe, T., Takai, J., Takada, H., Miyao, M.: Visibility and characteristics of the mobile phones for elderly people. Behavior \& Information Technology 21, 313-316 (2002)

2. Omori, M., Miyao, M., et al.: Visibility of mobile phones -Display characteristics and visual function. In: IEA 2003, Seoul, Korea (2003)

3. Fujikake, K., Mukai, M., Kansaku, H., Miyoshi, M., Omori, M., Miyao, M.: Readability for PDAs and LCD monitors among elderly people. Jpn. J. Ergonomics. 40, 218-227 (2004) (in Japanese)

4. Hasegawa, S., Irie, Y., Omori, M., Matsunuma, S., Miyao, M.: Visibility of graphical character e-mail in multiple languages on mobile phones: ESK and JES joint symposium 2004. Jpn. J. Ergonomics 40, 50-53 (2004)

5. Sato, K., Okamoto, K., Miyao, M.: Multilingual and ubiquitous information system for disasters: ESK and JES joint symposium 2004. Jpn. J. Ergonomics 40, 88-91 (2004)

6. Miyao, M., Hacisalihzade, S.S., Allen, J.S., Stark, L.W.: Effect of VDT resolution on visual fatigue and readability: an eye movement approach. Ergonomics 32, 603-614 (1989)

7. ISO 9142-3: Ergonomic requirements for office work with visual display terminals (VDTs) (1992)

8. JIS S 0032: Guidelines for the elderly and people with disabilities -Visual signs and displays- Estimation of minimum legible size for Japanese single character (2003) 